сті пухлини, а також у виконанні ряду паліативних хірургічних операцій та заходів, що покращують якість життя пацієнта.

У дослідженні взяли участь 571 пацієнт із різними формами перикардитів. Із них пухлинний - виявлено в 69 пацієнтів. Найбільшу группу склали пацієнти з вторинним ураженням перикарда метастазами з інших органів.

Представлено чотири клінічних випадки, за допомогою яких доказана ефективність перикардіоскопії як діагностичного, лікувального і паліативного заходу при пухлинному перикардиті.

Ключові слова: перикардит, перикардіоскопія, біопсія, променевий перикардит, злоякісні новоутворення, паліативні хірургічні втручання.

\title{
PERICARDIOSCOPY IN COMPLEX OF DIAGNOSTIC, CURATIVE AND PALLIATIVE PROCEDURES FOR MANAGING TUMORAL PERICARDITIS (CLINICAL EXPERIENCE)
}

\section{G.N. Ursol}

Abstract. By the examples of clinical cases, the paper shows the advisability of using pericardioscopy in complex of detecting tumoral pericarditis, its effectiveness relative to verification of tumor nature, and performing variety of palliative surgical procedures, which improve the quality of patients life.

571 patients with various forms of pericarditis were involved in the study. Among them 69 patients were diagnosed with its tumor form. The major group consisted of patients with secondary damage of the pericardium by metastasis from other organs.

4 clinical cases are presented which prove the effectiveness of pericardioscopy as diagnostic, curative and palliative surgical procedures for oncologic lesion.

Key words: pericarditis, pericardioscopy, biopsy, radiation pericarditis, malignant tumors, palliative surgery.

Medical centre PE "Hospital of St.Luke” (Kirovograd)

Рецензент - проф. В.П. Польовий

Buk. Med. Herald. - 2015. - Vol. 19, № 1 (73). - P. 181-189

Надійшла до редакції 20.02.2015 року

(C) Г.Н. Урсол, 2015

УДК 616.61-002-091-092

\author{
О.С. Федорук, М.С. Степанченко
}

\section{ФУНКЦІОНАЛЬНІ ЗМІНИ КОНТРЛАТЕРАЛЬНОЇ НИРКИ В РІЗНІ ТЕРМІНИ ПІСЛЯ ВИДАЛЕННЯ УРАЖЕНОГО ОРГАНА ЗА ГОСТРОГО ОДНОБІЧНОГО ЗАПАЛЕННЯ НИРОК У ЩУРІВ}

Буковинський державний медичний університет, м. Чернівці

Резюме. 3 метою визначення ступеня впливу ураженої нирки на функціональну активність контрлатерального органа, першу видаляли в різні терміни від початку експерименту. Нефректомію з ураженого боку проводили на 10-ту, 14-ту та 21-шу добу експерименту. Функціональні показники резидуальної нирки досліджували через 4, 7 та 14 діб від нефректомії. Показники порівнювали з аналогічними в інтактної нирки на таку ж добу експерименту у щурів, що не піддалися нефректомії з ураженого боку. Визначено, що після видалення

Вступ. Однобічне ураження нирок запального характеру становить неабияку актуальність у клініці, адже число пацієнтів із гострим однобічним пієлонефритом залишається великим і не має тенденції до зниження. В Україні щороку збільшується число зареєстрованих випадків хворих 3 інфекцією нирок на 1 \%, показники захворюваності для пієлонефриту загалом і хронічного пієлонефриту становили 1621,0 та 1437,6 на 100 тисяч населення відповідно [1]. При цьому нез'ясованими залишаються особливості функціонування інтактної нирки, а також механізми залучення іiї в (C) О.С. Федорук, М.С. Степанченко, 2015 ураженої нирки у всіх підгруп тварин змінювалися практично всі показники функції контрлатерального органа по відношенню до таких, де нефректомія не проводилася. Рання нефректомія - на 10-ту та 14-ту добу - призводила до нормалізації функціональних показників та розвитку компенсаторної реакції з боку резидуальної нирки до 28-ї доби.

Ключові слова: запалення нирок, пієлонефрит, контрлатеральна нирка, інтактна нирка, нефректомія.

запальний процес $[2,3,8]$. Тому усвідомлення принципів поведінки сечової інфекції в організмі та механізмів взаємодії ураженої та контрлатеральної нирок допоможе оптимізувати інтенсивність лікувально-діагностичної допомоги пацієнтам, залежно від терміну та ступеня тяжкості хвороби.

Мета дослідження. Визначити особливості змін деяких функціональних показників роботи контрлатеральної нирки в різні терміни після видалення ураженого органа за гострого однобічного запалення нирок у щурів. 
Матеріал і методи. Експеримент здійснено на 54 статевозрілих нелінійних білих щурах Ratttus Norwegicus чоловічої статі, віком 18-20 тижнів, масою 180-205 г. Всім тваринам моделювали гострий однобічний запальний процес нирок за власною методикою [4,5]. До основної групи увійшли 36 щурів, останніх розподілено на три підгрупи: I (n=18) - виконано нефректомію з ураженого боку на 10-ту добу експерименту; II $(\mathrm{n}=12)$ - виконано нефректомію з ураженого боку на 14-ту добу експерименту; III (n=6) - виконано нефректомію $з$ ураженого боку на 21-шу добу експерименту. Функціональні показники роботи резидуальної нирки за рутинними методиками визначали на 14-ту (Ia, n=6), 21-шу (Iб, n=6; IIa, $\mathrm{n}=6$ ) та 28-му добу (Ів, n=6; ІІб, $\mathrm{n}=6$; III, n=6). Контрольну групу склали 18 тварин, функціональні показники роботи контрлатеральної нирки в яких вивчали на 14-ту $\left(\mathrm{K}_{1}, \mathrm{n}=6\right), 21$-шу $\left(\mathrm{K}_{2}, \mathrm{n}=6\right)$ та 28-му добу $\left(\mathrm{K}_{3}, \mathrm{n}=6\right)$ за власною методикою [6, 7]. Показники обчислювали статистично за рутинними методиками із використанням критерію Стьюдента. Критичний рівень значущості при перевірці статистичних гіпотез у даному дослідженні приймали рівним 0,05

Результати дослідження та їх обговорення. У всіх підгруп тварин відразу після нефректомії відбувалося підвищення швидкості клубочкової фільтрації (ШКФ), на значення тим більше, чим раніше виконано нефректомію з ураженого боку. Варто зауважити, що у випадку показників Іа на 14-ту добу період від виконання нефректомії становив лише чотири доби, тоді як у всіх інших мінімальний період реєстрації змін - сім діб, тому спостерігалося не надто різке зростання. У підгрупі III на 28-му добу відбувалося незначне порівняно 3 іншими компенсаторне зростання ШКФ, що дало змогу припустити розвиток незворотних змін у контрлатеральній нирці. У підгрупи II зростання показника сповільнювалося між 21-ю і 28-ю добами, у той час як у тварин, котрим видалено уражену нирку на 10-ту добу, даний показник показував зворотний ріст, залишаючись, тим не менше, вищим від таких у контролю та підгрупи III. Така ситуація пояснювалася ймовірним різким компенсаторним підвищенням клубочкової фільтрації з подальшим (після встановлення гомеостатичної рівноваги) поверненням до комфортного режиму роботи органа.

На підтвердження такому припущенню слугували дані динамічної зміни концентрацій креатиніну в плазмі крові, як основного індикатора фільтраційно-реабсорбційної функції нирок. Так, у кожній підгрупі, після видалення ураженої нирки, спостерігалося зростання рівня креатиніну крові. Таке зростання рівнів креатиніну після видалення ураженого органа ймовірно було пов'язаним 3 тим, що останній також ніс певне функціональне навантаження, яке контрлатеральна нирка, внаслідок включення в процес, не могла скомпенсувати відразу.

Так, темп приросту (7,81\%) був найнижчим у підгрупі Іа на 14-ту добу, що, зокрема, й обумовлено меншим терміном спостереження (чотири доби). Проте простежувалася тенденція до збільшення темпу приросту даного показника в підгрупи IІа на 21-шу добу (18,7 \%) та підгрупи III на 28-му добу $(27,8 \%)$, що могло свідчити про зниження компенсаторних можливостей контрлатеральної нирки з часом або ж розвиток незворотних змін у паренхімі. Після різкого підйому дані показники знижувалися в підгрупах Іб, Ів та ІІб до значень, нижче таких у групи порівняння.

У групах I та II відбувалося різке зменшення значень концентрацій білка в сечі після видалення ураженої нирки по відношенню до контролю, починаючи з 21-ї доби, практично не відрізняючись, проте в Іа на 14-ту добу (ймовірно за рахунок меншого проміжку часу). Тим не менше, у підгрупі III відбулося підвищення концентрації білка в сечі на 28-му добу, що свідчило про зростаюче пошкодження ниркової паренхіми, ймовірно незворотного характеру. У той же час зниження видалення білка із сечею, як маркера пошкодження всіх відділів нефрону, після видалення ураженої нирки на 10-ту та 14-ту добу наштовхувало на думку про позитивний вплив ранньої нефректомії на контрлатеральний орган.

Підтверджували попереднє припущення зміни показників транспорту натрію, що становить

Таблиця 1

Показники функції контрлатеральної нирки щурів на 14-ту добу (x $\pm \mathrm{Sx})$

\begin{tabular}{|c|c|c|}
\hline Показники, що досліджуються & $\mathrm{K}_{1}(\mathrm{n}=6)$ & Ia $(\mathrm{n}=6)$ \\
\hline Діурез, мл/2год/100г & $1,93 \pm 0,154$ & $2,28 \pm 0,178^{*}$ \\
\hline Концентрація креатиніну в плазмі, мкмоль/л & $218,12 \pm 11,334$ & $273,43 \pm 14,153^{*}$ \\
\hline ШКФ, мкл/хв/100г & $142,61 \pm 12,85$ & $198,46 \pm 10,99^{*}$ \\
\hline Концентрація білка в сечі, мг/мл & $0,182 \pm 0,022$ & $0,179 \pm 0,019$ \\
\hline Екскреція білка, мг/2 год/100г & $0,351 \pm 0,054$ & $0,408 \pm 0,053^{*}$ \\
\hline Концентрація натрію в сечі, ммоль/л & $3,54 \pm 0,855$ & $3,85 \pm 1,419$ \\
\hline Екскреція натрію, ммоль/2 год/100г & $6,75 \pm 1,54$ & $8,94 \pm 3,84$ \\
\hline Реабсорбція натрію, ммоль/хв/100г & $19,89 \pm 1,89$ & $27,55 \pm 1,52^{*}$ \\
\hline
\end{tabular}

Примітка. * - різниця достовірна 
Таблиця 2

Показники функції контрлатеральної нирки щурів на 21-шу добу (x $\pm \mathrm{Sx})$

\begin{tabular}{|c|c|c|c|}
\hline Показники, що досліджуються & $\mathrm{K}_{2}(\mathrm{n}=6)$ & Iб $(\mathrm{n}=6)$ & IIa $(\mathrm{n}=6)$ \\
\hline Діурез, мл/2год/100г & $1,78 \pm 0,12$ & $2,60 \pm 0,173^{*}$ & $2,55 \pm 0,145^{*}$ \\
\hline Концентрація креатиніну в плазмі, мкмоль/л & $188,7 \pm 14,86$ & $258,9 \pm 19,25^{*}$ & $149,9 \pm 8,6 * \circ$ \\
\hline ШКФ, мкл/хв/100г & $127,99 \pm 9,09$ & $246,8 \pm 16,46^{*}$ & $285,8 \pm 11,7 * \circ$ \\
\hline Концентрація білка в сечі, мг/мл & $0,177 \pm 0,021$ & $0,125 \pm 0,014 *$ & $0,078 \pm 0,01 * \circ$ \\
\hline Екскреція білка, мг/2 год/100г & $0,312 \pm 0,032$ & $0,325 \pm 0,046$ & $0,197 \pm 0,02 * \circ$ \\
\hline Концентрація натрію в сечі, ммоль/л & $2,22 \pm 0,303$ & $1,78 \pm 0,209 *$ & $0,84 \pm 0,1 * \circ$ \\
\hline Екскреція натрію, ммоль/2 год/100г & $3,93 \pm 0,44$ & $4,63 \pm 0,63 *$ & $2,13 \pm 0,20^{* \circ}$ \\
\hline Реабсорбція натрію, ммоль/хв/100г & $17,95 \pm 1,32$ & $33,97 \pm 2,09 *$ & $40,02 \pm 1,7 * \circ$ \\
\hline
\end{tabular}

Примітка. ${ }^{*}$ - різниця з $\mathrm{K}_{2}$ достовірна; ${ }^{\circ}$ - різниця з Іб достовірна

Таблиця 3

Показники функції контрлатеральної нирки щурів на 28-му добу (x \pm Sx)

\begin{tabular}{|c|c|c|c|c|}
\hline Показники, що досліджуються & $\mathrm{K}_{3}(\mathrm{n}=6)$ & Ів $(\mathrm{n}=6)$ & ІІб (n=6) & IIIa (n=6) \\
\hline Діурез, мл/2год/100г & $1,74 \pm 0,13$ & $2,17 \pm 0,18^{*}$ & $2,60 \pm 0,20^{* \circ}$ & $1,94 \pm 0,17^{* \circ} \sim$ \\
\hline $\begin{array}{c}\text { Концентрація креатиніну в плазмі, } \\
\text { мкмоль/л }\end{array}$ & $185,55 \pm 8,34$ & $241,2 \pm 16,9^{*}$ & $168,2 \pm 13,8^{* \circ}$ & $102,66 \pm 12,6^{* \circ} \sim$ \\
\hline ШКФ, мкл/хв/100г & $119,14 \pm 7,92$ & $145,4 \pm 14,3^{*}$ & $271,7 \pm 10,6 * \circ$ & $216,3 \pm 15,66^{* \circ} \sim$ \\
\hline Концентрація білка в сечі, мг/мл & $0,114 \pm 0,021$ & $0,18 \pm 0,02^{*}$ & $0,08 \pm 0,01^{* \circ}$ & $0,054 \pm 0,018^{* \circ} \sim$ \\
\hline Екскреція білка, мг/2 год/100г & $0,200 \pm 0,045$ & $0,39 \pm 0,03^{*}$ & $0,202 \pm 0,04^{\circ}$ & $0,104 \pm 0,031^{* \circ} \sim$ \\
\hline Концентрація натрію в сечі, ммоль/л & $1,79 \pm 0,23$ & $2,82 \pm 0,8^{*}$ & $0,84 \pm 0,11^{* \circ}$ & $0,80 \pm 0,09^{* \circ}$ \\
\hline Екскреція натрію, ммоль/2 год/100г & $3,11 \pm 0,33$ & $6,18 \pm 2,14^{*}$ & $2,17 \pm 0,28^{* \circ}$ & $1,54 \pm 0,22^{* \circ} \sim$ \\
\hline Реабсорбція натрію, ммоль/хв/100г & $16,75 \pm 1,07$ & $20,28 \pm 2,09^{*}$ & $38,04 \pm 1,4^{* \circ}$ & $30,97 \pm 2,22^{* \circ} \sim$ \\
\hline
\end{tabular}

Примітка. * - різниця з К 3 достовірна; ${ }^{\circ}$ - різниця з Ів достовірна; - різниця з ІІб достовірна

не менш важливий показник ушкодження нефрону. У групі III спостерігалося підвищення концентрації останнього в сечі на 28-му добу відносно контролю, у той час як групи Ів та ІІб демонстрували аналогічне до білка зниження рівнів даного електроліту в сечі.

\section{Висновки}

1. Нефректомія 3 ураженого боку супроводжувалася компенсаторним підвищенням швидкості клубочкової фільтрації контрлатеральної нирки та зниженням натрійурезу і виділення білка із сечею.

2. Транзиторне зростання рівня креатиніну плазми крові після нефректомії в подальшому заміщувалося його спадом.

3. Видалення ураженої нирки на 10-ту та 14-ту добу призводило до нормалізації функціональних показників роботи нирок до 28-ї доби; видалення ураженої нирки на 21-шу добу супроводжувалося подальшими функціональними розладами нирки, що залишилася.

Перспективи подальших досліджень. Перспективним $є$ подальше дослідження гістопатологічних та мікробіологічних змін тканин контрлатеральної нирки в різні терміни після видалення ураженого органа за гострого однобічного запального процесу нирок у щурів.

\section{Література}

1. Сайдакова Н.О. Основні показники урологічної допомоги в Україні за 2006-2007 роки (відомче видання) / Н.О. Сайдакова, Л.М. Старцева, Н.Г. Кравчук. - К.: Поліум, 2008. -210 c.

2. Гоженко А.І. "Приховане" ушкодження проксимального відділу нефрону / А.І. Гоженко, Ю.С. Роговий, О.С. Федорук // Одес. мед. ж. - 2001. - № 5. C. 16-19.

3. Пішак В.П. Універсальність ушкодження проксимального канальця при захворюваннях нирок / В.П. Пішак, В.В. Білоокий, Ю.С. Роговий // Бук. мед. вісник. 2005. - Т. 4, № 1. - С. 72-76.

4. Пат. 72206 Україна, МПК: G09B 23/28 (2006.01). Спосіб моделювання вторинного пієлонефриту / Федорук О.С., Степан В.Т., Степанченко М.С., Візнюк В.В.: заявник і власник Буковинський державний медичний університет МОЗ України; заявл. 03.02.2012, опубл. 10.08.2012. Бюл. № 15/2012.

5. Пат. 75119 Україна, МПК: A61D 7/00 Спосіб моделювання гострого запалення нирок та паранефрію / Степан В.Т., Іфтодій А.Г., Федорук О.С., Степанченко M.С.: заявник i власник Буковинський державний медичний університет МОЗ України; заявл. 17.04.2012, опубл. 26.11.2012. Бюл. № 22/2012.

6. Степанченко М.С. Спосіб моделювання гострого вторинного обструктивного пієлонефриту у щурів / 
М.C. Степанченко, О.С. Федорук: матеріали 95-ї підсумкової конференції професорсько-викладацького персоналу Буковинського державного медичного університету, присвяченої 70-річчю БДМУ (Чернівці, 17,19, 24 лютого 2014 р.). - Чернівці: Медуніверситет, 2014. - C. 131-132.

7. Степанченко М.С. Метод роздільного отримання сечі з кожної нирки при експериментальному пієлонефриті у щурів / Степанченко М.С., Стецив О.В., Владиченко К.А. // Хист. - 2014. - № 16. - С. 225

8. Kurihara S. Acute bacterial pyelonephritis: Pathogenesis, pathophysiology, and therapy / S. Kurihara, Y. Miyazaki, S. Kohno // Nippon Rinsho. - 2006. - Vol. 64, Suppl. 2. P. 572-575.

\title{
ФУНКЦИОНАЛЬНЫЕ ИЗМЕНЕНИЯ КОНТРАЛАТЕРАЛЬНОЙ ПОЧКИ В РАЗНЫЕ ТЕРМИНЫ ПОСЛЕ УДАЛЕНИЯ ПОРАЖЕННОГО ОРГАНА ПРИ ОСТРОМ ОДНОСТОРОННЕМ ВОСПАЛЕНИИ ПОЧЕК У КРЫС
}

\section{А.С. Федорук, М.С. Степанченко}

Резюме. С целью определения степени влияния пораженной почки на функциональную активность контралатерального органа, первую удаляли в разные термины от начала эксперимента. Нефрэктомию с пораженной стороны проводили на 10-ые, 14-ые и 21-ые сутки эксперимента. Функциональные показатели оставшейся почки исследовали через 4, 7 и 14 суток после нефрэктомии. Показатели сравнивали с аналогичными в интактной почке на такие самые сутки эксперимента, у крыс, которым не проводилась нефрэктомия с пораженной стороны. Определено, что после удаления пораженной почки у всех подгрупп животных изменялись практически все показатели функции контралатерального органа по отношению к таким, где нефрэктомия не проводилась. Ранняя нефрэктомия на 10-ые и 14-ые сутки - приводила к нормализации функциональных показателей и развития компенсаторной реакции со стороны резидуальной почки до 28 суток.

Ключевые слова: воспаление почек, пиелонефрит, контралатеральная почка, интактная почка, нефрэктомия.

\section{INTACT KIDNEY'S FUNCTIONAL CHANGES IN COURSE OF THE ACUTE UNILATERAL KIDNEY INFLAMMATION IN RATS: DIFFERENT TIME FRAMES AFTER NEPHRECTOMY ON THE AFFECTED SIDE}

\section{O.S. Fedoruk, M.S. Stepanchenko}

\begin{abstract}
An affected kidney was removed in various terms of the experiment in order to determine its influence on functional activity of the intact kidney. Nephrectomy on the affected side was performed on the $10^{\text {th }}, 14^{\text {th }}$ and $21^{\text {st }}$ days. Functional scores of the residual kidney were evaluated 4, 7 and 14 days after nephrectomy. Control group constituted animals without nephrectomy. Scores were compared to the respective ones of the intact kidney in control group, on the same day of experiment. Reliable changes of almost all functional kidney scores were detected after removal of the affected organ. Early nephrectomy (on the $10^{\text {th }}$ and $14^{\text {th }}$ days) evoked compensatory reaction of the residual kidney and resulted in normalization of functional parameters on the $28^{\text {th }}$ day.
\end{abstract}

Key words: kidney inflammation, pyelonephritis, contralateral kidney, intact kidney, nephrectomy.

Bukovinian State Medical University (Chernivtsi)

Рецензент - проф. Ю.Є. Роговий
Buk. Med. Herald. - 2015. - Vol. 19, № 1 (73). - P. 189-192

Надійшла до редакції 26.02.2015 року

(C) О.С. Федорук, М.С. Степанченко, 2015 